\title{
Russia's foreign policy towards North Africa in the wake of the Arab Spring
}

\author{
by \\ Tobias Schumacher, Chairholder, ENP Chair, College of Europe (Natolin campus) \\ Ulica Nowoursynowska 84 \\ PL-02-797 Warsaw, Poland \\ Tel.: +48.604.351.269 \\ Fax: +48.22.64.91.352 \\ Email: tobias.schumacher@coleurope.eu
}

$\&$

Cristian Nitoiu, Research Assistant, Department of Political Science, Trinity College Dublin 1 College Green

Dublin 2, Ireland

Email: c.nitoiu@ outlook.com

Correspondence Address: Tobias Schumacher, ENP Chair, College of Europe (Natolin campus). Email: tobias.schumacher@coleurope.eu

\begin{abstract}
Since coming to power in 2000, Russian president Vladimir Putin has tried to construct a narrative of regaining Russia's status as a major global power. However, in practice the Kremlin is yet to have created a coherent strategy or to have achieved a sense of coordination in foreign policy. While North Africa has not been at the forefront of this narrative, recently Moscow has intensified its diplomatic links and cooperation with the regimes in the region. The Arab Spring presented Russian policy-makers with a series of challenges regarding the uncertainty of the developments in the region, but also with renewed economic opportunities. This profile analyses Moscow's relationships with the countries in North Africa (Libya, Egypt, Morocco, Tunisia and Algeria) in the wake of the Arab Spring. In each case the Kremlin aimed to take advantage of the new opportunities without really being guided by an overarching strategy for the region. However, Russia increasingly seems to be keen to position itself in the region as an alternative to EU or the US, not least in light of the crisis in Ukraine.
\end{abstract}




\section{1 words}

The current crisis in Ukraine has put the spotlight on Russian foreign policy. This has involved questioning the factors which influence Moscow's foreign policy, together with the instruments it uses to pursue its goals. Much of this attention has focused on the way in which Russia is trying to regain its former hegemony in the post-Soviet space. More generally though, Russia has constructed a multi-vector foreign policy, in that it has focused simultaneously on various vectors (loosely defined regions - e.g. the Transatlantic, Eurasian or the Oriental one). Since Putin came to power in 2000, the development of a long termstrategy has not been one of the cornerstones of this multi-vector foreign policy, as vectors have changed many times. Recently, the southern Mediterranean has become such a vector due to its increasing importance in economic terms for Russian foreign policy. Yet, Russia's approach towards the region is influenced by the overall lack of strategy in Russian foreign policy, but also Moscow's fear of the Arab world, or its willingness to support some regimes in the region that oppose western influences whilst also collaborating with the US and the EU in order to combat Islamic extremism. It is of particular relevance here that in Russian foreign policy the southern Mediterranean is mainly circumscribed to parts of the Mashreq and North Africa. Moreover, in contrast to the EU or the US, both of which have aimed to build comprehensive strategies for the region, Moscow has preferred to deal bilaterally with the states in the region (or ad-hoc groups of states).

The Arab Spring and the popular uprisings that unfolded puzzled Russian policy-makers considerably and made them fear that events might spill-over to the post-Soviet space and to Russia and the North Caucasus in particular. To this end, this profile explores Moscow's approach towards the southern Mediterranean in the wake of the Arab Spring. Rather than looking at the region as a whole, it draws on Russia's approach and analyses recent and rather overlooked developments in its bilateral relations with the countries of North Africa, such as Libya, Egypt, Morocco, Tunisia and Algeria. Before engaging in the country specific analysis, the profile first looks briefly at the complex nature of policy-making in Russian foreign policy in general and will then conclude by synthesizing some of the findings and also offer insights into how Moscow's approach towards the region might evolve in the future. It finds that the Kremlin seems keen to take advantage of new opportunities offered by the Arab Spring. However, if Russia is to be successful in its efforts it should devise an overarching approach towards the region rather than focusing solely on bilateral relations.

\section{Russian foreign policy under Putin}

The absence of a coherent strategy in Russian foreign policy is predicated upon the power struggle between various groups. These groups support different vectors according to their interests and ideas about Russia's role in international relations. Policy-makers in foreign policy have grouped according to their willingness to collaborate with the West, their preference to be treated as an equal by the US or the EU, or the desire to promote (or impose) a Russian understanding of international relations globally. Putin's goal has been to try to centralize Russian foreign policy and instil a sense of coordination and strategy. This strategy 
is seen to be crucial for pursuing effectively Russia's global interests. It entails the creation and promotion of a narrative which emphasizes Russia's return to the status of a major global power which does not only have to be treated as an equal by Europe or the US, but also to be able to project its own values globally. The 2008 Russian-Georgian war, Russia's involvement in Ukraine or its increasing claims over the Artic stand out as practical manifestations of this narrative. Moreover, Putin has banked on his achievements and ambitions in foreign policy in order to strengthen his domestic support in the context of increasing contestation of his legitimacy in the Russian public sphere. Consequently, internally he has emphasized continuity (or a commonly shared 'civilizing 'mission) between the global ethos of imperial Russia and the Soviet Union. For example, across Russia statues of Lenin stand next to statues resurrected from the Tsarist era.

The extent to which Putin's efforts have been successful is very questionable, but Russia's approach to the crisis in Ukraine or the development of the Eurasian Union are evidence of an emerging pattern of coordination in Russia's approach towards the post-Soviet space. Other regions, such as North Africa are yet to receive this level of attention from Putin, and have not been directly linked to the narrative of continuity and great power revival. Moscow's approach towards them is still very much influenced by the various interests of the groups in Russian foreign policy. What this all points to, is the decentralized, ad-hoc and bilateral nature of Russia's engagement with countries in the southern Mediterranean. Russia's involvement in this region is informed mostly by economic interests such as energy relations and the increasing penetration of the region in this area by Russian companies, but also in regards to arms trade where Russia is seeking to re-discover, maintain or even enlarge its Cold War markets. During the Cold War the North African countries were caught in between the influence of the US and the Soviet Union. Some of these states experienced alternating periods of Soviet and American influence: for example, Egypt leaned first in the 50s and 60s towards the Soviet Union, and then reversed its policy aligning to the US in the 70s. Both superpowers aimed to establish a foothold in the region, whilst also pursuing their own economic interests - for the Soviet Union this involved mainly securing and enhancing markets for its military industry. These relations have carried on after the break-up of the Soviet Union and have even been strengthened since Putin came to power.

The Arab Spring created significant losses to the Russian military and defence industry due to the breakdown of several defence contracts (of around 10 billion dollars), making Moscow less willing than the US or the EU to support revolutionary forces that bring about change in the region. The Kremlin also perceived the overthrow of autocratic (and rather stable) regimes as a threat to regional stability. On the other hand, the Arab Spring raised important questions for Russia's foreign policy regarding the contagion of radical Islam, terrorism and public uprisings in North Africa and their possible spill-over to the post-Soviet space or its own territory. These concerns stem from the lack of understanding of the Muslim world together with Moscow's fear that predominantly Muslim areas on its territory might try to gain independence. The next section builds on these insights into Russian foreign policy and analyses its bilateral engagement in North Africa. 


\section{Russia's bilateral engagement in North Africa}

\section{Libya - from partner to stranger?}

After the suspension of international sanctions in April 1999 and their subsequent lifting by the UN Security Council in September 2004, Libya aligned itself increasingly with the West, mainly as a result of mere power considerations and the notion that such a move would ensure the survival of Qaddafi's regime. In parallel, Russia worked towards resuming its close economic ties that had existed for almost two decades up until the early nineties, hoping that it could re-establish itself as Libya's main arms supplier. Putin, to date the only Russian president that ever visited Libya, went to Tripoli in April 2008 and in exchange of writing-off approx. \$4.5 billion that Libya had owed to Russia, signed, or agreed in principle on, numerous contracts over economic, technical, and military cooperation supposedly worth $\$ 10$ billion. As a result of Qaddafi's further intensification of economic and diplomatic relations with the US, the United Kingdom and France, Russia was however unable to capitalize on these contracts, and Putin's and Gazprom's strategic objective, i.e. to purchase all Libyan oil and gas, thus exerting effective control of Libyan hydrocarbon supplies to Europe and EU member states, never materialized.

The prospect of controlling all Libyan energy supplies has become even more unlikely as Russia throughout the last three years failed to shake off its image as a counter-revolutionary force and long-standing supporter of the Qaddafi regime. Interestingly, this notion persisted among both members of the National Transition Council (NTC), armed militia and the General National Congress (GNC) in spite of Russia's abstention to provide coherent support to Qaddafi forces in the context of the Libyan civil war. In fact, while Russia abstained from approving UN Security Council resolution 1973 in March 2011, then President Medvedev in May 2011 even declared that Qaddafi had lost his legitimacy and should resign. The reason why such announcements were, however, insufficient to break with perceptional patterns was that they reflected the stance of only one faction inside the Kremlin which also boasted alternative, yet powerful voices. Putin and foreign minister Lavrov for example considered any external involvement in Libya as a breach of Libya's sovereignty and therefore strongly opposed the decision by the UN panel of experts on Libya on 20 March 2011 that arms supplies were, in fact, under certain conditions compatible with UNSC resolution 1973.

Unsurprisingly, such fragmented views did not resonate well with Libyans in general and neither did Russian accusations claiming that the Libyan authorities hosted training facilities for foreign fighters engaged in overthrowing Syrian president Bashar al-Assad. In conjunction with repeated announcements in 2012 and 2013 by the NTC that countries that participated in the NATO-led military campaign against the Qaddafi regime should be rewarded with preferential treatment, these factors accelerated considerably the trend, already visible since 1999, of a dwindling Russian presence in Libya. This is exemplified by the fact that up until the outbreak of renewed violence in mid-2014 and the subsequent evacuation of the Russian embassy staff in August 2014, Gazprom was unsuccessful in securing a much envisaged stake in the ENI-led Elephant oil field $800 \mathrm{~km}$ south of Tripoli. Similarly, Rosoboronexport, Russia's state agency in charge of arms exports, did not manage to revive existing arms 
contracts or secure new ones, and also Russian infrastructure companies, such as Russian Railways (RZhD), supposedly participating in a Chinese-led consortium destined to construct a $554 \mathrm{~km}$ railway line between the cities of Benghazi and Sirte, were unable to compete with other, mainly US and western European corporations.

\section{Egypt-new opportunities, new honeymoon?}

While Russia failed to capitalize in Libya on the US' relative retreat from the Middle East in general, the military coup of 3 July 2013 in Egypt offered Russia new avenues to achieve several objectives at the same time. In fact, the current and rather rapidly evolving rapprochement between Russia and Egypt is seen by many in Moscow as an opportunity to project the Kremlin's global aspirations and to drive a wedge between Cairo and Washington. Yet, the warming of relations is not the result of a pro-active strategy on the part of Russia, but occurs mainly in response to global re-balancing efforts by the Egyptian regime of president Abdel-Fattah el-Sisi, Egyptian ambitions to pursue a more multi-dimensional, independent and pro-active foreign policy, and the regime's attempts to exploit the power rivalry between the US and Russia, not least in light of the Ukraine crisis.

Whereas Egypt already in recent pre-Arab Spring times occasionally half-heartedly flirted with Russia, current advances, numerous high-level meetings, and the conclusion of several wide-ranging agreements indicate the emergence of a true partnership of convenience. After visits by the head of the Russian military intelligence in Cairo and unprecedented meetings on the level of foreign and defence ministers in the autumn/winter of 2013/2014, and the setting up of a Russian-Egyptian commission on trade and economic cooperation in late March 2014, el-Sisi in August 2014 chose Moscow, and not Washington, for his first visit outside the region. Even though foreign minister Lavrov, defence minister Shoigu and eventually president Putin, were deeply concerned about the Muslim Brotherhood's temporary rise to power and had refused to approve of an Egyptian loan request over US $\$ 2$ billion during Morsi's reign, were quick in making unconditional cooperation offers, hoping for a quick revival of the close ties that existed during Soviet times in the 1950s and 1960s. Indeed, talks were successful as an agreement was reached in principle over the supply of MIG-29 fighter jets, Ka-25 and Mi-28 attack helicopters, and Kornet anti-tank missile systems. Russia has repeatedly supplied the latter to Syrian president Bashar al-Assad, and which amount to roughly US\$3 billion. In spite of Saudi Arabia’s opposition to opposes Russia's Syria policy, it has been financing the arms deal. It also reached further agreement with respect to the initiation of close cooperation in the field of anti-terrorism supposedly targeting militant Islamists, joint military exercises, training Egyptian officers at Russian military academies, the fight against piracy, and Russian support for Egypt's nuclear energy ambitions. Moreover, Putin himself ensured that Gazprom will deliver throughout 2015 several shipments of gas, based on a rate below market prices and to be paid at a later stage. He also convinced el-Sisi to enter into negotiations with the Eurasia Customs Union and to set up a Russian industrial zone in the context of the envisaged Suez Canal project. So far at least, these unconditional offers paid off for Moscow. The Egyptian regime committed itself to increase considerably its 
agricultural exports to Russia, thus helping the latter to bypass western sanctions imposed on Russia as a consequence of its unlawful actions in eastern Ukraine. Finally Egypt refrained from voting on a resolution in the UN General Assembly calling on all UN member states to not recognize Russia's annexation of Crimea.

\section{Tunisia - relational upswing or convergence of needs?}

Generally speaking, similar dynamics are discernible as far as recent developments in Russia's relations with Tunisia are concerned. The outbreak of the Jasmine revolution in January 2011, the fall of Ben Ali's autocratic regime and, subsequently, En-Nahda's decision to relinquish power in late 2013/early 2014, changed Russian-Tunisian dynamics. Since autumn 2013 it has generated a momentum that, has culminated in the conclusion of a trade agreement, stipulating an increase of Tunisian agricultural exports to compensate for Russian import gaps as a result of western sanctions as well as a general agreement to cooperate closely in the fight against terrorism, and a Russian grant over US\$500 million. Even though the recent upswing in Russian-Tunisian relations indicates a break with the past, it does not necessarily imply a major foreign policy shift towards the relevant other by either side. Instead, it is the consequence of a temporary convergence of needs. On the one hand, Russia is desperate to find alternative trade partners to minimize the effects of western sanctions. On the other hand, the intensification of relations with Russia is simply a matter of economic and financial necessity for Tunisia, given the country's socio-economic situation in the current climate of transition. Yet, these efforts are under no circumstances intended to undermine Tunisia's close links with the EU and, to a lesser extent, the US.

\section{Morocco - strategic partnership or temporary partnership of convenience?}

Like Tunisia, Morocco still relies extensively on France, the EU and the US as regards its political, economic and financial support. Notwithstanding, the royal palace has already on several occasions in the past used the prospect of a potential deepening of ties with the Soviet Union/Russia as a bargaining chip to extract more concessions and benefits. It is in this light that current efforts by the Moroccan and Russian regime to expand their bilateral cooperation have to be understood. Thus, the Kremlin's overtures, particularly visible since the outbreak of the Ukrainian crisis, vis-à-vis what it considers to be a strategic partner - Morocco is Russia's most important phosphate supplier and shares similar views on issues related to noninterventionism and self-determination in general - have been received positively by Rabat. This is the case also because its relations privilégiées with France are currently in a state of crisis and as recent attempts by the US and others to expand the United Nations Mission for the Referendum in Western Sahara (MINURSO) mandate beyond merely supervising the referendum for the possible separation of Western Africa from Morocco. Another aspect of the US' strategy has involved adding a human rights compliance element have served as an unwelcome reminder that western, rather pro-Moroccan perspectives on the future of Western Sahara might be subject to change. Against this backdrop Russia's ad-hoc engagement is 
characterized mainly by the initiation of high-level foreign ministers meetings. The fifth meeting of a joint commission took place in September 2014 and was tasked to identify new areas for cooperation, meetings of high-ranking military personnel, and the RussianMoroccan summit to be held in Moscow in October 2014. These diplomatic activities follow a period in 2011-2013 during which Russia acted more as a bystander, supporting rhetorically the royal palace's approach to the demands of the 20 February Movement. To date, this activism has resulted in the conclusion of several agreements, allowing Russia to export wheat - a commodity that until the outbreak of the war in Ukraine was supplied in considerable amounts by Kyiv -, and to increase imports of Moroccan agricultural produce. From the Kremlin's perspective this shall be complemented by the timely conclusion of oil and gas contracts and, equally important, arms supplies, the latter of which, if they ever materialized, have the potential to break Morocco's dependence on European and USAmerican weaponry imports.

\section{Algeria - back to the future?}

In contrast, Russian efforts to revitalize relations with Algeria, during the Cold War one of the Soviet Union's closest allies on the African continent, already date back to 2001 when Putin and president Bouteflika signed a strategic partnership agreement. On the one hand it aimed at facilitating the resumption of Russian arms deliveries and the exploration of joint cooperation initiatives in the hydrocarbon sector. On the other hand it was supposed to provide the Algerian regime with much needed international legitimacy after years of violent conflict. In fact, as far as military cooperation is concerned, Russia, which is occasionally training Algerian counterterrorist forces, has managed to increase considerably its arms supplies to Algeria. If between the early 1960s to the late 1980s, Algeria imported already almost $80 \%$ of its equipment from Russia, between 2003 and 2012 Rosoboronexport and the Russian military complex increased sales by more than 10\%, making Algeria the third most important customer of Russian weapons. In the hydrocarbon sector, however, and in spite of the conclusion of a memorandum of understanding between Gazprom, Lukoil and the Algerian government-owned company Sonatrach in 2006 to collaborate in the area of liquefied natural gas and oil fields exploration, and the decision by Sonatrach in December 2008 to grant Gazprom exploration and exploitation rights in the El Assel field, Russia's presence was rather limited. This changed only in February 2014 when Sonatrach and thus the Algerian regime invited Gazprom to participate in an international tender for the exploration and development of 30 fields that make up one fifth of Algeria's territory. While this invitation is the outcome of eight years of bilateral negotiations, it has to be seen mainly in light of Algeria's urgent need to explore new hydrocarbon deposits, not least in view of its rising domestic energy consumption, and as a reward of sorts for the Kremlin's support of the regime throughout Arab uprisings in 2011 and its supposedly unconditional cooperation offers. Conversely, Putin used this new dynamic and, being aware of Algeria's intentions to build a nuclear power plant by 2025 , offered also close and preferential cooperation in the nuclear energy field - a development that in early September 2014 led to the conclusion of a bilateral agreement between Rosatom, Russia's state agency in charge of nuclear energy 
cooperation, and the Algerian ministry of energy, stipulating the construction, operation and servicing of nuclear power stations and research reactors all across Algeria.

\section{Conclusions}

The current intensification of diplomatic relations and expansion of cooperation between Russia and North African countries has become possible because a growing number of regimes in the region are seeking opportunities to minimize growing uncertainty among western actors over the prospects of post-Arab Spring developments. As a result, their logics of action are rooted in the belief that a possible rapprochement with Russia can be used as a bargaining chip vis-à-vis the US and EU member states, as well as a mechanism destined to generate economic and financial gains. Under the impression of western sanctions and the prospect of international isolation, Russia has become increasingly aware of these considerations and, particularly since mid-, late-2013 is trying to transform them into mutual win-sets, even though, as is the case in Russia-Algeria relations, it sometimes follows just past practices or acts merely as a responsive rather than a pro-active actor. However, this is bound to change if the current rift between Russia and the West deepens. This possibility is reflected in the new security doctrine that defence minister Shoigu and Russian generals presented to high ranking military representatives from Algeria, Egypt, Libya and 38 other countries in late May 2014 and that regards the US as a dangerous nation seeking to dismantle Russian statehood and destabilize governments around the world. In other words, there is a high probability that Russia will increasingly seek to position itself in North Africa and beyond as an alternative to the West. However, the extent to which such an approach can succeed depends to a considerable degree on Arab regimes' dependence on the US and the EU, as well as on their individual bargaining power. While Egypt seems to be the most likely to continue to snub Washington, others, such as Tunisia and Morocco, will try to balance and seek to consolidate their close relations with both Russia, the EU and the US in order to increase their individual room for manoeuvre and to respond pre-emptively to the US's relative retreat from the Middle East and North Africa in general. To benefit from such dynamics as much as possible, however, it seems to be vital for the many actors involved in Russia's foreign policy to define and agree on an overarching set of interest as far as North Africa is concerned and then devise an approach that is based on differentiation and country specificities. However, given the rather ad-hoc nature of Russian foreign policy making and the rather evolving and open-ended developments in the region itself this is not likely to happen any time soon. 